12.

\title{
NAJRANIJA RECEPCIJA \\ MARXOVE MISLI MEĐU \\ JUŽNIM SLAVENIMA U HABSBURŠKOJ \\ MONARHIJI I SRBIJI (1848. - 1871.)'
}

\section{Matko Globačnik}

UDK: $141.82: 808.53(497) “ 1848 / 1871^{“}$

Izvorni znanstveni članak

Sažetak: Hrvatska, srpska i slovenska historiografija, čak i kada je djelovala u okviru iste države, nikada nije bila jedinstvena u svojoj metodologiji, niti je pokušala komparativnom historijom doći do novih spoznaja u istraživanju najranije recepcije modernih socijalističkih učenja i najranijih početaka radničkog pokreta. Ovaj rad slijedi metodologiju suvremene nemarksističke zapadnoeuropske i sjevernoameričke historiografije, a iz te perspektive bavi se zanemarenom „pretpoviješću“ hrvatske, srpske i slovenske socijaldemokracije u vidu istraživanja najranije recepcije Marxove misli među Južnim Slavenima u Habsburškoj Monarhiji i Srbiji. Kao početna vremenska točka rada uzeta su revolucionarna zbivanja 1848., a kao završna Pariška komuna 1871. godine jer su to bili povijesni događaji koji su izazivali intelektualne rasprave, o kojima je opširnije izvještavao hrvatski, srpski i slovenski tisak i u kojima je konačno Marx imao zamjetniju ulogu. Na kraju rada izlažu se rezultati istraživanja dobiveni komparacijom recepcije Marxove misli među Hrvatima, Srbima i Slovencima.

Ključne riječi: Karl Marx, komunizam, socijalizam, Habsburška Monarhija, Banska Hrvatska, Dalmacija, slovenske pokrajine, Kneževina Srbija, intelektualna historija

\section{UVOD}

$[?$

natoč tomu što je povijest radničkog pokreta te socijalističkih i komunističkih ideja među Hrvatima, Srbima i Slovencima zbog političkih prilika bila aktualna tema u drugoj polovini 20. stoljeća, u historiografiji tih naroda, nakon političkih promjena krajem istoga stoljeća, ona je gotovo posve napuštena. Umjesto da slobodnije društvenopolitičke okolnosti, uvjetovane nestankom subjekta vlasti, kojemu je interpretacija povijesti marksizma bila ideološka legitimacija, budu poticaj za temeljitiju refleksiju o postignućima

1 Ovaj je rad u poprilično drugačijoj formi bio izložen 4. listopada 2016. na Institutu za književnost i umetnost u Beogradu u okviru Desničinih susreta 2016. godine. Posebno zahvaljujem Stanislavi Barać i Vesni Matović na plodonosnoj diskusiji koja se razvila tom prilikom te anonimnim recenzentima koji su mi dali vrijedne sugestije. 
i promašajima dotadašnje historiografije te za povezivanje s razvijenom nemarksističkom historiografijom u zapadnim zemljama, kao i za postavljanje ciljeva budućih istraživanja, od te su teme profesionalni znanstvenici odustali. Time je stvoren dubok rez u razvoju historiografije, a važan dio moderne i suvremene hrvatske povijesti ostao je neistražen. Ovaj je rad stoga malen doprinos većoj temi povijesti socijalističkih i komunističkih ideja i uopće početaka moderne radikalne ljevice te mu je glavni cilj u društveno-povijesnom kontekstu prikazati prvu recepciju Marxovih ideja među Hrvatima u komparaciji s tom recepcijom među Srbima i Slovencima. Time se on uklapa u temu Desničinih susreta 2016., koja problematizira relevantnost povijesnih tema za današnji hrvatsko-srpski, odnosno srpsko-hrvatski interkulturalizam. Kao vremenski početna točka rada uzeta su revolucionarna zbivanja 1848., a kao završna Pariška komuna 1871. godine jer su to dva događaja koja su imala znatniji odjek među Južnim Slavenima, pri čemu je u njima Marx imao zamjetniju ulogu te je zbog toga i njegova misao među tim narodima postajala poznata.

\section{ENIGME HistoriogRAFIJE}

Temeljna djela najranije povijesti radničkog pokreta i socijalističkih ideja dala su pečat hrvatskoj, srpskoj i slovenskoj historiografiji tijekom čitavog 20. stoljeća. U hrvatskoj i slovenskoj historiografiji, gdje se najranija recepcija socijalističkih ideja datira u vrijeme postojanja Habsburške Monarhije, ta su djela u međuratnom razdoblju napisali prvi socijaldemokrati rođeni krajem sedamdesetih i početkom osamdesetih godina 19. stoljeća. Generacija o kojoj je riječ svoju je političku svijest oblikovala u fin-de-siècleu i vrhunac političke aktivnosti doživjela je u vrijeme vrhunca njemačke i austrijske socijaldemokracije, što se poklapalo s (barem za marksiste) idejno bogatim razdobljem Druge internacionale pred Prvi svjetski rat. Radi se, naravno, o djelima socijaldemokratskih prvaka Vitomira Koraća i Antona Kristana. ${ }^{2}$ Često potpomognuti vlastitim, kao i sjećanjima svojih drugova, oni su udarili temelje društvenoj historiji koncentrirajući se ponajprije na radničku svakodnevicu i opširno opisujući organizacijsku, ekonomsku, kulturnu i političku sferu života te djelovanja radnika i socijalista iz perspektive socijaldemokracije. Iako je u poslijeratnoj Jugoslaviji hrvatska, odnosno slovenska historiografija dobila poticaj u obliku osnivanja Instituta za historiju radničkog pokreta, odnosno Inštituta za zgodovino delavskega gibanja, došla do novih rezultata, obrnula gledište i socijaldemokraciju promatrala iz komunističke perspektive, u bavljenju najranijom poviješću kao da je naslijedila raniju ograničenost na društvenu povijest, što nije pridonosilo propitkivanju stare Koraćeve tvrdnje da u najranijoj povijesti radničkog pokreta među Hrvatima (ali i Slovencima) „ni prizvuka nema nikakovih modernih socijalističkih stremljenja i teoretisanja, kako ih tada npr. nalazimo u socijalno i ekonomski daleko slabije razvijenijoj kneževini Srbiji“.”3

2 Vitomir Korać, Povijest radničkog pokreta u Hrvatskoj i Slavoniji, knj. I-III, Zagreb 1929. - 1933.; Anton Kristan, O delavskem in socijalističnem gibanju na Slovenskem do ustanovitve jugoslovanske socijalnodemokratične stranke (18481896), Ljubljana 1927.

3 V. Korać, Povijest radničkog pokreta u Hrvatskoj i Slavoniji, knj. III, 92. Najviše se Koraćevim interpretacijama usprotivio Josip Cazi u svojoj knjizi Prva radnička društva u Hrvatskoj (1860-1880), Zagreb 1957. Za primjere bavljenja radničkim pokretom u Banskoj Hrvatskoj i Dalmaciji (do 1871.) u hrvatskoj historiografiji dodatno usp. Mir- 
Za razliku od hrvatske i slovenske historiografije koje su se bavile isključivo društvenom poviješću, u Srbiji se još prije Prvoga svjetskoga rata razvijala intelektualna historija koja je $\mathrm{u}$ fokusu imala socijaliste intelektualce, kako pokazuje dobro poznati primjer Jovana Skerlića, ${ }^{4}$ a takav trend nastavljen je i u međuratnome periodu, iako se tada intelektualna počinje povezivati s društvenom historijom. ${ }^{5}$ Pa i poznata djela izašla u socijalističkoj Jugoslaviji, koja su doticala ili su se posve bavila najranijom poviješću socijalističkih ideja i radništva u Srbiji, dobrim su dijelom ili u potpunosti pripadala intelektualnoj historiji. ${ }^{6}$

Na prvi pogled, sasvim drugačiji razvoj hrvatske, slovenske i srpske historiografije u vezi s najranijom poviješću radništva i socijalističkih ideja bio je posve logičan jer je ovisio o prošloj zbilji. Slovenske pokrajine i Banska Hrvatska bile su gospodarski razvijenije od Dalmacije i Srbije i u njima se rano javljaju radnička udruženja, ali ne i značajniji mislioci socijalističkog usmjerenja. S druge strane, Srbija je dala značajne socijaliste intelektualce, iako su oni djelovali u okruženju posvemašnje industrijske nerazvijenosti i maloga broja radnika. Ipak, nikada se nije raspravljalo o uzrocima takva stanja, a historiografija je u drugoj polovini 20. stoljeća došla do novih spoznaja koje su revidirale takve teze, pa postaje zagonetno zašto ona nije razvila druge pristupe $u$ istraživanju početaka radničkog pokreta. Tim se zagonetkama mogu dodati i druga pitanja koja su otvorena, ali na koja se nikada nije konačno odgovorilo. Primjerice, kakva su bila radnička gibanja prije 1869. u Banskoj Hrvatskoj i Dalmaciji, jesu li postojale veze tamošnjih radničkih društava s Prvom internacionalom, kako su se ta društva organizirala te kakva je bila njihova ilegalna djelatnost?7

Pored otvorenih pitanja, može se reći i da metodološki pristupi dosadašnje historiografije ne zadovoljavaju. U bavljenju intelektualnom historijom presudno je proučavati same izvore različitih socijalističkih i komunističkih učenja u njihovu društveno-povijesnom kontekstu kako bi se uvidjele fine nijanse koje obilježavaju njihove međusobne razlike, konstelacijskim istraživanjem vidjeti kako su se i u kojim uvjetima ta učenja posredovala, prihvaćala i prevodila, kao i (kako bi se izbjegao teleološki način interpretacije povijesti) istraživati koje su se poteškoće javile u njihovu razvoju. ${ }^{8}$ Dakako da ovaj rad neće ulaziti u sva ova

jana Gross, „Počeci radničkog pokreta u Zagrebu“, Historijski zbornik, 8/1955., 1-39; Stjepan BlažEković, Pomoćni priručnik za historiju medunarodnog radničkog pokreta i historiju KPJ, Zagreb 1958., 94-102; Miroslava Despot, „Počeci radničkog pokreta i političke prilike u Hrvatskoj u doba Pariške komune“, Pariška komuna 1871-1971 (ur. Pero Damjanović i Ašer Deleon), Beograd 1971., 965-983; Stijepo ОваD, „Odjek Pariške komune u stranačkom životu Dalmacije“, Pariška komuna 1871-1971 (ur. Pero Damjanović i Ašer Deleon), Beograd 1971., 984-988; Vlado OšTrić, „Prilozi pitanjima početaka radničke i socijalističke štampe u sjevernoj Hrvatskoj (1869-1890)“, Počeci socijalističke štampe na Balkanu (ur. Milo Popović i dr.), Beograd 1974., 45-84. Za primjere slovenske historiografije v. Ferdo Gestrin, „Uticaj Pariške komune na politički razvoj u Sloveniji“, Pariška komuna 1871-1971 (ur. Pero Damjanović i Ašer Deleon), Beograd 1971., 1037-1050.

Jovan SkerLIĆ, Svetozar Marković. Njegov život, rad i ideje, Beograd 1910.

5 Dragiša LAPČEvić, Istorija socijalizma u Srbiji, Beograd 1922.

6 Vasa Ćubrilović, Istorija političke misli u Srbiji XIX. veka, Beograd 1982., 203-241; Sergije Dimitrijević, Socijalistički radnički pokret u Srbiji 1870-1918, Beograd 1982.; Latinka Perović, Srpski socijalisti 19. veka, knj. I-II, Beograd 1985.

7 Prema Mirjani Gross, moderni radnički pokret u Hrvatskoj počinje 1869. akcijom za modernu radničku organizaciju, koja je bila potaknuta iz Beča. M. Gross, „Počeci radničkog pokreta u Zagrebu“, 2; M. Despot, „Počeci radničkog pokreta i političke prilike u Hrvatskoj u doba Pariške komune“, 971-972; S. OвAD, „Odjek Pariške komune u stranačkom životu Dalmacije“, 985.

8 O takvoj metodologiji usp. Marcelo R. Sтамм, „Konstellationsforschung - Ein Methodenprofil: Motive und Perspektiven“, Konstellationsforschung (ur. Martin Mulsow i Marcelo Stamm), Frankfurt am Main 2005., 31-73. 
otvorena pitanja, koja se ostavljaju za drugu priliku, već je za potrebe ovoga zbornika njegov cilj skromniji, a taj je pristupom nemarksističke zapadne historiografije istražiti prvu recepciju Marxove misli među Hrvatima, Srbima i Slovencima na temelju tadašnjeg tiska i dosadašnje historiografije.?

\section{Prvotna recepcija Marxovih ideja u Banskoj Hrvatskoj i Dalmaciji}

Godinu 1848. obilježila su revolucionarna događanja u Europi. Marx je u veljači objavio Das Manifest der Kommunistischen Partei, a ubrzo je protjeran iz Bruxellesa, pa u ožujku odlazi u Pariz, gdje reorganizira Savez komunista, koji poziva na ujedinjenje njemačkih zemalja u jedinstvenu republiku i (među ostalim) zagovara nacionalizaciju plemićkih i crkvenih dobara, transportnih i gospodarskih objekata te besplatno obrazovanje. U lipnju Marx odlazi u Köln, gdje okuplja istomišljenike koji su se shvaćanjima suprotstavljali drugim komunističkim grupama, poglavito onoj Mosesa Hessa i Andreasa Gottschalka. Zasigurno je najvažnije postignuće Marxove grupe pokretanje lista Neue Rheinische Zeitung, koji izlazi u velikoj nakladi i čita se u najudaljenijim dijelovima njemačkoga govornog područja. On komentira europska revolucionarna događanja, kritizira pretežito liberalni Parlament u Frankfurtu na Majni, držanje vodećih krugova u Prusiji i Rusiji te sve što je obilježeno kao „kontrarevolucionarno“. ${ }^{10}$ Kao takvi obilježeni su i Južni Slaveni u Habsburškoj Monarhiji, kojima je Engels odricao budućnost jer im tobože „nedostaju povijesni, zemljopisni, politički i industrijski uvjeti samostalnosti i sposobnosti za život", ali je zapravo razlog osude ležao u njihovu oštrom suprotstavljanju „progresivnim“ Mađarima. ${ }^{11}$ Međutim, slijedom okolnosti revolucionarna su zbivanja neslavno završavala, a s njima i Marxova predviđanja te je on od svibnja 1849., kada je protjeran s pruskog teritorija, gledao njihovu postupnu propast te se ljeti iste godine povukao u London, gdje će ostati do kraja života. ${ }^{12}$

U Banskoj Hrvatskoj za Marxa još 1845. znaju Gajeve Novine horvatsko-slavonsko-dalmatinske i Agramer politische Zeitung. Ti su zagrebački listovi izvještavali o zabranjivanju tjednika Vorwärts koji je izlazio u Parizu na njemačkom jeziku te o progonu „neka dvanaest komunističkih književnikah“, među kojima je bio i Marx, pri čemu su kao poticatelji progona ispravno prepoznate pruske vlasti. ${ }^{13}$ No, iako se i prije komunizam u tim novinama spominjao u negativnom svjetlu, tek od revolucionarne 1848. spominjanje te ideje postaje

9 Dobar je primjer suvremenog istraživanja i historiziranja Marxova lika i djela, čije se interpretacije slijede u ovome radu, nova biografija Marxa iz pera američkog povjesničara Jonathana Sperbera, stručnjaka za revolucije 1848. i za radikalne skupine tijekom toga razdoblja, iako je on uskim profesionalnim ograničenjem na povijest deficitaran u nekim područjima poput filozofskih aspekata Marxova djela.

10 Franz Mehring, Gesammelte Schriften, Bd. III: Karl Marx. Geschichte seines Lebens, Berlin 1960., 160-190; Jonathan Sperber, Karl Marx. A Nineteenth Century Life, New York 2013., 194-236.

11 Friedrich Engels, „Der demokratische Panslawismus“, Karl Marx i Friedrich Engels, Werke, Bd. VI, Berlin 1961., 275.

12 J. Sperber, Karl Marx, 243.

13 „Francezka“, Novine horvatsko-slavonsko-dalmatinske (Zagreb), br. 15, 19. 2. 1845., 59; „Frankreich“, Agramer politische Zeitung (Zagreb), br. 16, 22. 2. 1845., 64. O listu Vorwärts i Marxovu progonu iz Francuske v. F. MeHring, Karl Marx, 85-94; J. Sperber, Karl Marx, 150-152. 
češće, dakako, samo u Zagrebu jer je dalmatinski tisak posve nezainteresiran za tu temu, stoga se njen spomen vrlo rijetko mogao naći u člancima Zore dalmatinske ili L'Avvenirea. ${ }^{14}$ Tako, kada je tijekom svibnja došlo do radikalizacije stanja u Beču, otpuštanja konzervativnih ministara i careva bijega u Innsbruck, Novine (koje je tada uređivao Bogoslav Šulek) su primijetile da bečki „proleteri (...) neće da rade jer su im glave pune kojekakvih buntovnih i komunističkih ideah" ${ }^{15}$ U listopadu je Jelačić stezao obruč oko glavnoga grada Monarhije koji je mjesec ranije posjetio i Marx, a Novine su prenosile vijesti bečkih novina (koje su „stenjale“ pod „terorizmom bečkih radikalacah") da je sâm ban izjavio kako među tamošnjim pobunjenim žiteljstvom „svaki hoće da zapoveda a nitko neće da sluša“, pa zbog toga i nemaju šanse protiv dobro organizirane vojske. ${ }^{16}$

Takva shvaćanja podupirao je i članak koji se pojavio u prosincu u Agramer Zeitungu, a u kojem se tvrdilo da je jedna od najvećih opasnosti za jedinstvo Austrije, pa i opstanak svake države upravo komunizam. On je definiran kao pojava idealizma u politici koja apstrahira od svega „pozitivnog i povijesnog“ te čiji ideal nije niti dobar niti u sebi sadrži zrnce istine, a to je država kakva nikada ne može postojati. Spomenuti idealizam zastupa neimenovana škola što privlači mlade i neiskusne koji sanjaju o promjeni svijeta te koja zahtijeva ,jednakopravnost svih“, unatoč očitoj različitosti sposobnosti pojedinaca, i daje masama „prava koja u neiskusnim rukama postaju opasno oružje“. Takvu državu pokušava ostvariti mala prevrtljiva skupina koja zapravo nema idealistička uvjerenja, ali zbog vlastite ambicije i gramzivosti „diže revolucije“ pod svaku cijenu, čime uzrokuje samo „pomutnju, anarhiju i jad“, kako su pokazali krvavi događaji u Beču. Ti ljudi ne znaju vladati i nemaju rješenja ni za najjednostavnija praktična pitanja, dakle oni znaju samo rušiti i širiti kaos, tvrdi se u članku. ${ }^{17}$ Sličnih se primjera, u kojima se komunizam identificira sa zlim fantazijama, lijenošću i neradom, kaosom i anarhijom, može naći još mnogo. Još jedan od rijetkih članaka koji se u cijelosti posvetio komunizmu objavljen je u Novinama u kolovozu 1848. Njegov anonimni autor tvrdio je da se komunizam ne može spomenuti „bez šal““ jer po njegovoj „djetinjskoj“ teoriji, društvo treba urediti „tako kako su uredjeni manastiri ili samostani, gdje je sve obćinsko, a ništa vlastito, te gde nije mesta za strasti niti za rodbinu“. Kao glavni „apostol“ komunizma navodi se rani socijalist Étienne Cabet, koji ne priznaje nasilje te braćom smatra i bogate i siromašne, ali čije je učenje „ludorija“ koja služi kao maska onima koji žele uvesti anarhiju i nered. Autor članka pozitivnim ocjenjuje francuskoga generala Louis-Eugènea Cavaignaca te branu protiv širenja komunizma vidi u mjerama koje bi uslijedile nakon nedavnog ukidanja feudalnih odnosa, ali ne bi štetile postojećemu političkom poretku. Kao primjer predlaže davanje zemlje seoskim vijećima, što bi zaštitilo vlasništvo i pridonijelo izglađivanju suprotnosti društtvenih klasa. ${ }^{18}$

14 O revoluciji 1848. u Banskoj Hrvatskoj i Dalmaciji v. Nikša Stančrć, „Godina 1848.“, Hrvatska i Europa. Kultura, znanost i umjetnost, sv. IV: Moderna hrvatska kultura od preporoda do moderne (XIX. stoljeće) (gl. ur. Mislav Ježić), Zagreb 2009., 63-75.

15 „Dalmacia, Hervatska i Slavonia“, Novine dalmatinsko-hervatsko-slavonske (Zagreb), br. 51, 20. 5. 1848., 205.

16 "Trojedna kraljevina i vojvodovina serbska“, Novine dalmatinsko-hervatsko-slavonske (Zagreb), br. 115, 19. 10. 1848. 763.

17 „Die Gefahren für die Einheit Oesterreichs“, Agramer Zeitung (Zagreb), br. 138, 2. 12. 1848., 611.

18 „Komunizam“, Novine dalmatinsko-hervatsko-slavonske (Zagreb), br. 89, 19. 8. 1848., 357-358. Nešto drugačijeg mišljenja o odnosu komunizma prema kršćanstvu, koje je smatrao posve oprečnim, bio je anonimni autor uvodnika u Narodnim novinama (Zagreb), br. 89, 13. 7. 1849., 343. 
Iz navedenih izvora može se zaključiti da je ono što su zagrebačke novine identificirale kao „komunizam“ zapravo predstavljalo više lijevih struja koje su zastupale razne (komunističke, anarhične i rane socijalističke) ideje. Novine su se pod Šulekovim uredništvom u pogledu pojave novih revolucionarnih ideja najviše koncentrirale na Francusku, pa Proudhona nazivaju najumnijim i najdjelatnijim komunistom, nigdje ne spominju Neue Rheinische Zeitung, a znaju da su pariški „komunističko-anarhički journali“ Le peuple, La république, La révolution démocratique et sociale, La démocratie pacifique i La réforme, od kojih je u potonjem Engels objavljivao članke, a i Marx jedno pismo odlaskom iz Bruxellesa. ${ }^{19}$ Dakako, komunizam se vrlo često, kao i posvuda u Europi u to vrijeme, upotrebljavao kao pogrdan naziv kojim su se obilježavali neistomišljenici. ${ }^{20}$

I u desetljeću poslije revolucionarnih zbivanja, dakle tijekom Bachova apsolutizma, može se u Banskoj Hrvatskoj naići na spominjanje Marxova imena. Tako već 1850. ban Jelačić u Bachovo ime prosljeđuje velikim županima obavijest da pripaze na širenje ideja „kakova se samo po Marxu i Engelsu (u Londonu) goje“. ${ }^{21}$ Gajeve Narodne novine u ožujku 1852., izvještavajući o hvatanju Mazzinijevih privrženika u Parizu, spominju da su oni bili u vezi s pristašama „poznatog Marxa“, a znaju i za Engelsa kao bivšeg urednika Neue Rheinische Zeitunga te za Savez komunista u Londonu. ${ }^{22}$ Ipak, sve su to tek usputna spominjanja vijesti uglavnom preuzetih iz stranog tiska te nema vatrenih rasprava o komunizmu kao za vrijeme revolucije 1848./1849. godine. Tek u drugoj polovini šezdesetih godina, jačanjem njemačke i austrijske socijaldemokracije, počinju se ponovno spominjati Marxove ideje. ${ }^{23}$ Upravo je jedno od prvih spominjanja Marxova glavnog djela Das Kapital (1867.) i Prve internacionale na hrvatskome jeziku opširmiji izvještaj o okupljanju socijaldemokrata Austrije i Njemačke u Beču u srpnju 1869. godine (malo prije donošenja Eisenachskog programa), a koji je objavljen u Narodnim novinama. Članak je prenio govor Wilhelma Liebknechta, kao i govore drugih socijaldemokrata, a time i sljedeći važan podatak:

Jeseni god. 1865. sastavljeno je medjunarodno radničko družtvo u Londonu, koje se je sada razširilo po svih zemljah i koje nastoji oživotvoriti ono, što je Karl Marx pisao u svojem

19 „Francezka“, Novine dalmatinsko-hervatsko-slavonske (Zagreb), br. 17, 8. 2. 1849., 67; „Francezka“, Novine dalmatinsko-hervatsko-slavonske (Zagreb), br. 21, 17. 2. 1849., 83. Osim Engelsa, u La réforme su radove objavljivali rani socijalist Louis Blanc te anarhisti Pierre-Joseph Proudhon (koji je uređivao Le peuple) i Mihail Aleksandrovič Bakunjin, a La démocratie pacifique pokrenuo je socijalist Victor-Prosper Considerant. Listovi o kojima je riječ većinom su bili zabranjeni već početkom 1849. V. K. Marx i F. Engels, Werke, 325-327, 536-538; Morna Daniels, „French Newspapers and Ephemera from the 1848 Revolution“, British Library Journal, 24/1998., 224.

20 Taktikom denunciranja protivnika kao „pravih komunista“ koristio se i sam Marx. V. J. Sperber, Karl Marx, 213.

21 Citirano prema M. Despot, „Počeci radničkog pokreta i političke prilike u Hrvatskoj u doba Pariške komune“, 966. „Iz Pariza, 24. ožujka“, Narodne novine (Zagreb), br. 72, 29. 3. 1852., 198; „Iz Londona 28. veljače“, Narodne novine (Zagreb), br. 59, 12. 3. 1850., 159; „Francezka“, Narodne novine (Zagreb), br. 222, 27. 9. 1951., 640.

23 Za socijalno pitanje u šezdesetima u Banskoj Hrvatskoj zanimljive su dvije pojave. Prva je knjiga Lazara HelleNBACHA, Misli o socialnoj politiki u Austriji, Zagreb 1862. U njoj se pokazuje da je Hellenbach svjestan socijalnoga pitanja, ali je daleko od bilo kakve marksističke teorije (najviše citira knjigu Wilhelma Heinricha Riehla, Die Naturgeschichte des Volkes als Grundlage einer deutschen Social-Politik) te se iz pozicije zemljoposjedničkog plemstva zalaže za drugačiju raspodjelu bogatstva unutar postojećega društvenog sistema. Druga je važna pojava serija članaka u Zatočniku 1869. godine koja se bavila radničkim pitanjem, ali je također bila (kao i svi drugi članci) daleko od Marxovih shvaćanja, pozivajući se na njemačkog teoretičara prava Roberta Mohla i posve odbacujući komunizam. V. „Radničko pitanje I-IV“, Zatočnik (Sisak), br. 18, 24. 9. 1869.; br. 20-22, 27.-29. 9. 1869. O tome i sličnim člancima krajem šezdesetih i početkom sedamdesetih v. M. Gross, „Počeci radničkog pokreta u Zagrebu“, 8-10. 
djelu „Kapital“: Družtvena radnja na mjesto izsisavanja radnikah putem glavnice. Osobni kultus i sekterija udaljeni su od ovoga pokreta; njemu je do toga, da se načela izvedu. ${ }^{24}$

Dakle, dvije godine prije nego što je to dosadašnja hrvatska historiografija pretpostavljala, u Banskoj Hrvatskoj javno se spominje Prva internacionala. ${ }^{25}$ Iako je ona zapravo osnovana 1864., ime joj je dobro prevedeno kao „medjunarodno radničko družtvo“ (engl. International Workingman's Association, njem. Internationale Arbeiterassoziation), a i njena je ideologija odlično priopćena: Marxovo učenje u (tada nedavno objavljenom) djelu Das Kapital.

Kao što je dobro poznato, u trećoj četvrtini 19. stoljeća u Banskoj Hrvatskoj i Dalmaciji (paralelno s gospodarskim razvojem) osnivaju se i prva obrtnička i radnička društva koja isprva imaju dobrotvoran i (rjeđe) politički karakter. Već godine 1838. zagrebački tipografi u Gajevoj štampariji izborili su se za kućni red, a godinu kasnije i za socijalno osiguranje. U Varaždinu sredinom stoljeća postoji Tehnička čitaonica koja je imala politički cilj - povezati Košutove pristaše s revolucionarima u Parizu i Londonu - ali je raspuštena 1850. godine. U šezdesetima i početkom sedamdesetih Zagreb dobiva obrtničko i tipografsko društvo, Osijek je dobio radničko društvo (postoje i naznake postojanja tamošnjeg tipografskog društva), dok u Rijeci i Zadru postoje potporna društva. ${ }^{26} \mathrm{U}$ to vrijeme otvaraju se i moderne tvornice te počinju prve radničke demonstracije i štrajkovi u industrijski razvijenijim gradovima poput Osijeka. ${ }^{27}$

U takvu kontekstu primljene su u Banskoj Hrvatskoj i Dalmaciji vijesti o Francuskopruskom ratu, Pariškoj komuni te ulozi Marxa i Prve internacionale u tim zbivanjima. Isprva su Marx i Engels stajali na strani Prusije u tome sukobu, ali su odvijanjem ratnih događanja stali na stranu Francuske. Ipak, prema Pariškoj komuni, proglašenoj u ožujku 1871., Marx je bio rezerviran i nije u njoj nalazio obilježja budućega komunističkog društva kojem se nadao. No, kako je francuski i engleski tisak počeo napadati Prvu internacionalu, Marxa i komunizam zbog očajničkih nasilnih mjera Pariške komune, on je objavio The Civil War in France, kojim je podržao komunare, ponajprije kako bi obranio samu ideju komunizma. ${ }^{28}$ Time je, dakako, stekao publicitet u tadašnjem tisku, ali i položio temelj kasnijoj marksističkoj mitologiji o Pariškoj komuni kao primjeru prve „diktature proletarijata“.

Poznato je da je uglavnom cjelokupni tisak u Banskoj Hrvatskoj i Dalmaciji bio neprijateljski nastrojen prema Pariškoj komuni, a komunizam je opet prepoznat kao pokretač nasilja i „opaki izrod“ sa željom uništenja civilizacije. ${ }^{29}$ Narodne novine često su se najžešće

24 „U Beču, 26. srpnja (Narodna skupština)“, Narodne novine (Zagreb), br. 172, 30. 7. 1869., 337.

25 August Cesarec smatrao je da se ona prvi put spominje tek 1871., za vrijeme postojanja Pariške komune, a njega su u tome slijedili drugi hrvatski povjesničari. O tome v. malo niže u tekstu.

26 M. Despot, „Počeci radničkog pokreta i političke prilike u Hrvatskoj u doba Pariške komune“, 965-970. Istraživanje je Miroslave Despot o počecima radničkih društava (za sada) jedno od temeljitijih. Usp. i starije prikaze koji također sadrže vrijedne informacije: M. Gross, „Počeci radničkog pokreta u Zagrebu“; Josip CAzI, Prva radnička društva u Hrvatskoj (1860-1880), Zagreb 1957.; Isti, Radnički pokret Hrvatske 1860-1895, Beograd 1962.

27 M. Despot, „Počeci radničkog pokreta i političke prilike u Hrvatskoj u doba Pariške komune“, 972; Ista, „Nekoliko podataka o prilikama u zagrebačkoj tvornici koža 70-ih godina 19. stoljeća“, Historijski zbornik, 29-30/1976. - 1977., 377-383.

28 J. Sperber, Karl Marx, 374-383; K. Marx, The Civil War in France; K. Marx i F. Engels, Gesamtausgabe, erste Abteilung, Bd. XXII: Werke, Artikel, Entwürfe, März bis November 1871, Berlin 1978., 123-162.

29 „Komunizam“, Narodne novine (Zagreb), br. 135, 15. 6. 1871. O listovima u Dalmaciji v. S. OBAD, „Odjek Pariške komune u stranačkom životu Dalmacije“, 984-988. U historiografiji se često ističe tjednik Hervatska kao primjer simpatiziranja Pariške komune, zbog kratkih vijesti koje su se pisale pod utjecajem ideja mladih pravaša Frana Ma- 
obarale na komunare pa su tako u lipnju 1871. godine objavile proglas francuskog ministra Julesa Favrea. S obzirom na to da ga je Marx u svojem djelu The Civil War in France optužio za izdaju državnih interesa i blatio da živi u konkubinatu sa ženom nekog „pijandure“, nije čudno da je Favre za podupiranje Pariške komune javno prozvao Prvu internacionalu. ${ }^{30} \mathrm{Uz}$ to su Narodne novine i druge tiskovine prenijele informacije Timesa o Internacionali u kojima se tvrdilo da je njena „duša neki Niemac koji je prvi na to pomislio, da se teorije Babeufove, Diebnikove (?) i Proudhunove (!) uvedu i u Berlin“ “. ${ }^{31}$ Nakon propasti Pariške komune krenuo je lov na sve koji su mogli imati veze s Prvom internacionalom, pa su tako poznati slučajevi da su zbog toga optuženi krapinska učiteljica Marija Jambrišak te radnička društva u Osijeku i Splitu, ali bez čvrstih dokaza. ${ }^{32}$ Takvim neprijateljstvom prema novim radikalnim lijevim idejama umjereni hrvatski tisak započeo je sedamdesete godine, dakle, jednakim neprijateljstvom koje je iskazivao i tijekom revolucionarnih zbivanja 1848. godine.

\section{Marxova misao u SLOVEnSkim POKRajinama OD I848. DO I87I. GODINE}

Uvođenje slobode tiska u ožujku 1848. u Habsburškoj Monarhiji bilo je posebno vidljivo $\mathrm{u}$ slovenskim pokrajinama u povećanju broja tiskovina. Iako su one većinom bile kratkoga vijeka, značajno je da su se među njima pojavile i one na slovenskom jeziku. ${ }^{33} \mathrm{U}$ takvim uvjetima zanimljiva je razlika između slovenskih listova i novinstva Banske Hrvatske u pogledu učestalosti spominjanja komunizma. Ugledni list Laibacher Zeitung godinama prije revolucije poznaje riječ komunizam kao obilježje jedne struje poljskih emigranata, ${ }^{34}$ a već na početku revolucije, u ožujku 1848., kao da aludira na Das Manifest der Kommunistischen Partei kada govori o „sablasti komunizma“ (Gespenst des Communismus) koja se preko Alpa

tašića i Adolfa Jakšića. Međutim, treba istaknuti da pritom vjerojatno nije bila posrijedi simpatija za socijalističke i komunističke ideje, već se radilo samo o „epizodi“, izazvanoj „impresivnom pojavom Pariške komune, a vjerojatno i činjenicom da u tadašnjoj fazi razvoja socijalizma granica između proleterskoga socijalizma i radikalne građanske demokracije još nije bila povučena do kraja“, smatra Mirjana Gross, Izvorno pravaštvo. Ideologija, agitacija, pokret, Zagreb 2000., 300-301. Granica koju ona spominje svakako je bila jasna i povučena, ali je pitanje jesu li je prepoznali spomenuti mladi pravaši.

30 K. Marx, The Civil War in France, 125; „Favreova okružnica o uzrocih ustanka“, Narodne novine (Zagreb), br. 134135, 14.-15. 6. 1871.

31 Miroslava Despot smatrala je da se Prva internacionala prvi put spominje u Banskoj Hrvatskoj tek u ovome članku koji se pojavio u Narodnim novinama 13. lipnja 1871., neznatno ispravljajući Augusta Cesarca koji je smatrao da je vijest o Internacionali prva prenijela Kvaternikova Hervatska od 18. lipnja te godine. U svakom slučaju, u ovome radu iznesene činjenice pokazuju da Narodne novine već 1869. bolje poznaju ulogu Marxa i njegova djela Das Kapital u Prvoj internacionali, kao i da se Marx spominje u Banskoj Hrvatskoj najkasnije od 1845. godine. Inače je Diebnik, koji se javlja u ovoj vijesti, izmišljena osoba. V. M. Despot, „Počeci radničkog pokreta i političke prilike u Hrvatskoj u doba Pariške komune“, 979-981.

32 Isto, 970-972; S. ОвАD, „Odjek Pariške komune u stranačkom životu Dalmacije“, 985.

33 Marija Mojca Peternel, „Soziale, nationale und politische Emanzipation der Slowenen in der Zeitung im Jahre 1848“, Povijesni prilozi, 41/2011., 233-251. Za pregled događaja u slovenskim pokrajinama tijekom 1848. i 1849. usp. Ferdo Gestrin i Vasilij Melik, Istorija Slovenaca od kraja osamnaestoga stoljeća do 1918, Sarajevo 1979., 91-119 i Peter Vodopivec, Od Pohlinove slovnice do samostojne države, Ljubljana 2007., 51-62.

34 Vereinigte Laibacher Zeitung (Ljubljana), br. 39, 31. 3. 1846., 226.

35 „Lombardisch-Venetianisches Königreich“, Laibacher Zeitung (Ljubljana), br. 37, 24. 3. 1848., 252. 
nadvila nad sjevernotalijansko plemstvo. ${ }^{35} \mathrm{Nije}$ mu nepoznato niti djelovanje „republikanske demokracije“ u Kölnu kojoj je na čelu Savez pravednih, opasno tajno društvo koje želi svrgnuti sve europske dinastije i uspostaviti „svjetsku republiku“. ${ }^{36}$ Ipak, žestokih i satiričnih članaka protiv komunizma kao u Banskoj Hrvatskoj tijekom revolucije u najuglednijim slovenskim novinama nema. U novopokrenutim listovima kao što su Cillier Zeitung i Sloweniens Blatt nikada nije ni spomenuta riječ komunizam. Očito je da je hrvatski tisak puno češće i opširnije nego slovenski naglašavao „zloćudne“ komunističke struje koje su bile vidljive u revoluciji. ${ }^{37}$

Najznačajniji slovenski autor koji se neposredno nakon revolucije posvetio komunizmu bio je Vinko Fereri Klun u seriji članaka pod naslovom „Der Sozialismus und der Communismus" iz 1850. godine. ${ }^{38} \mathrm{Za}$ Kluna socijalizam i komunizam imaju izvor u starome germanskom društvu koje nije poznavalo razlika među pojedincima, a prvo teorijsko oblikovanje dao im je Rousseau. I socijalizam i komunizam teže ostvarenju jednakosti ljudi, ali prvi „kroz rad“, tj. dominaciju rada nad kapitalom, a drugi kroz „ukidanje cjelokupnog privatnog vlasništva“" ${ }^{39}$ Načelo jednakosti ljudi na kojemu učenje grade francuski filozofi, Rousseauovi sljedbenici, mora voditi padu postojećega državnog uređenja i supremaciji „nižih klasa“ nad trenutačno višima. Takve su ideje zbog otpora „vladajućih klasa“ uzrokovale rijeku krvi od 1789. godine, tvrdi Klun. On je kao dva najvažnija teorijska sistema socijalizma nabrojao onaj Saint-Simona i njegova učenika Amanda Bazarda te Fourierovo učenje, a oba je iscrpno opisao i sa svoga liberalnoga položaja negativno vrednovao kao „zanesenjaštvo“. ${ }^{40}$ Komunizam je, pak, za Kluna sustav kojega se „s pravom treba bojati“. Njega, doduše, još nitko nije oblikovao u „pravi sustav“, već su mu ideje raštrkane po raznim brošurama i pamfletima, a prvi teorijski istup učinio je $s$ „usrećiteljem čovječanstva“ François-Noëlom Babeufom za vrijeme Francuske revolucije, uz kojega Klun kasnije vezuje njemu bliske revolucionarne ličnosti: Augustina Darthéa, Sylvaina Maréchala i Philippea Buonarrotija. Glavni je cilj komunizma ostvariti „stalešku jednakost“ tako da u društvu vlada samo jedna klasa, a država bi u rukama imala cjelokupno obrazovanje koje bi se sastojalo samo u podučavanju čitanja. Ona mora upravljati državnim dobrom, cenzurirati „nepoćudni“ tisak, raspoređivati posao i određivati radno vrijeme, a ljudi bi trebali živjeti na malim posjedima umjesto u gradovima. Klun ismijava takva učenja te kao najnovije teoretičare komunizma navodi Blanca, Proudhona i Cabeta, čije teorije ukratko opisuje. ${ }^{41}$ Iz Klunovih se članaka jasno vidi da su se polovinom 19. stoljeća, kada Marxovo ime još

36 „Preußen“, Laibacher Zeitung (Ljubljana), br. 11, 25. 1. 1849., 50. Ovdje valja napomenuti kako Laibacher Zeitung ne zna da je Savez pravednih prije nešto više od godinu dana preustrojen u Savez komunista.

37 Možda je razlog tomu i činjenica da tim novim listovima nije odgovaralo spominjati komunizam u kontekstu revolucije, kojoj su oni zahvaljivali postojanje. O suprotstavljenosti stajališta novopokrenutog slovenskog i hrvatskog tiska v., primjerice, „Von der Leitha. Eine Stimme aus dem kroatischen Lager“, Cillier Zeitung (Celje), br. 61, 12. 12. 1848., 265-266.

38 O Klunu v. P. Vodopivec, O gospodarskih in socialnih nazorih na Slovenskem v 19. stoletju, Ljubljana 2006., 47-70.

39 Vinko Fereri Klun, „Der Socialismus und der Communismus I.“, Laibacher Zeitung (Ljubljana), br. 127, 6. 6. 1850., 583.

40 Isтi, „Der Socialismus und der Communismus II-III.“, Laibacher Zeitung (Ljubljana), br. 132, 12. 6. 1850., 605606; br. 140, 21. 6. 1850., 639-640.

41 Isti, „Der Socialismus und der Communismus IV.“, Laibacher Zeitung (Ljubljana), br. 144, 26. 6. 1850., 655-656. 
nije bilo poznato i istaknuto naspram drugih radikalnih teoretičara, u Ljubljani, kao i u Zagrebu orijentirali isključivo na francuske mislioce.

Ipak, moguće je da je Klun pri spominjanju raznih raštrkanih pamfleta i brošura koje zagovaraju komunizam mislio i na one Marxove. Jer, kako je rečeno, u istim novinama upadljivo se aludiralo na Das Manifest der Kommunistischen Partei, a samo nekoliko tjedana prije Klunovih članaka prvi se put spominje Marx, i to u kontekstu atentata na jednoga njemačkog kneza. Uzimajući informacije iz njemačkih novina koje su zastupale krajnje desne političke opcije, Laibacher Zeitung Marxa opisuje, zajedno s Arnoldom Rugeom, kao emisara propagande londonskog revolucionarnog komiteta. ${ }^{42}$

Sve do 1870. godine u slovenskome se tisku Marx ne spominje, a komunizam tek sporadično i isključivo u negativnome svjetlu. Kada bude uspostavljena Pariška komuna, slovenski će tisak, baš kao i hrvatski, prema njoj biti posve neprijateljski nastrojen ${ }^{43}$ te će više pažnje posvetiti Marxu i Prvoj internacionali. ${ }^{44}$ Tako je u gotovo isto vrijeme kada i u $\mathrm{Na}$ rodnim novinama (lipanj 1871.) ta organizacija, zahvaljujući bombastičnom Timesu, punila naslovnice Slovenskog naroda, koji ju je povezivao s Pariškom komunom i terorističkim metodama te je prenaglašavao brojnost njena članstva i njeno bogatstvo, ističući strogo centralističku organizaciju u čijem je središtu stajao Karl Marx. ${ }^{45}$ Iste su novine objavile Mazzinijeve optužbe da Marx i Internacionala zagovaraju ateizam koji vodi uništenju moralnog poretka i pravnog sustava. ${ }^{46}$ Takve optužbe u tisku nisu bile rijetkost u to vrijeme, ali ono što odvaja slovenski primjer od hrvatskog jest činjenica da se u vrijeme postojanja Pariške komune na slovenskome jeziku javlja opširnija učena rasprava o najnovijim socijalističkim učenjima, koja nije bila neprijateljska prema njima. Među radništvom u isto se vrijeme odigralo nekoliko važnih događaja, zbog kojih je 1871. obilježena kao „važna godina u povijesti slovenskoga socijalizma“" ${ }^{47}$

Važnu „socijalno-političku“ raspravu o socijalizmu napisao je slovenski pravnik Valentin Zarnik pod naslovom „Bivša parižka komuna in socijalizem“ u seriji članaka objavljenih u Novicama. On se uglavnom oslanjao na djelo Kapitalismus und Socialismus Alberta Schäfflea, ${ }^{48}$ koji je tada bio ministar u Hohenwartovoj Vladi. Zarnik, poput potonjega, ne slijedi slijepo Favreove optužbe protiv Prve internacionale, ${ }^{49}$ već socijalizam i komunizam želi nepristrano razjasniti. ${ }^{50}$ Socijalno je pitanje za njega prastaro pitanje „kruha“, odnosno osnovnog preživljavanja, ali tim se pitanjem nije bavila znanost, niti je ono imalo zastupni-

42 „Deutschland“, Laibacher Zeitung (Ljubljana), br. 121, 29. 5. 1850., 557-558.

43 Neprijateljski stav izražen je također prema austrijskim i njemačkim socijaldemokratima. V. V. MELIK, „Pariška komuna i Slovenci“, Pariška komuna 1871-1971 (ur. Pero Damjanović i Ašer Deleon), Beograd 1971., 1019. O navodnom sudioniku događaja u Parizu za vrijeme Pariške komune, Francu Železnikaru, v. isto, 1017-1018; F. Gestrin, „Uticaj Pariške komune na politički razvoj u Sloveniji“, 1044-1047.

44 Već prije početka Francusko-pruskog rata pojavljuju se vijesti o Marxu i Internacionali. V. „Der Generalrath der Internationalen Arbeiter-Assoziation“, Laibacher Zeitung (Ljubljana), br. 128, 8. 6. 1870., 923.

45 „Asocijacija 'International'“, Slovenski narod (Maribor), br. 74, 29. 6. 1871. Začuđujuće je pozitivan članak o Komuni „Pad 'komune’ v Parizu“, Slovenski narod (Maribor), br. 67, 13. 6. 1871.

46 „Mazzini o 'Internationale'“, Slovenski narod (Ljubljana), br. 87, 29. 7. 1871.

47 V. Melik, „Pariška komuna i Slovenci“, 1032.

48 Albert Eberhard i Friedrich Schäffle, Kapitalismus und Socialismus, Tübingen 1870.

49 Valentin ZARnik, „Bivša parižka komuna in socijalizem I.“, Novice (Ljubljana), br. 26, 28. 6. 1871., 204.

50 V. ZARNiK, „Bivša parižka komuna in socijalizem II.“, Novice (Ljubljana), br. 27, 5. 7. 1871., 216. 
ke do najnovijeg vremena. Među tim zastupnicima prvenstvo više nemaju samo Francuzi jer Zarnik, pod Schäffleovim utjecajem, ne nabraja samo Saint-Simona, Fouriera i Proudhona, već i Ferdinanda Lassallea, Karla Marloa (Karla Georga Winkelblecha) i konačno Marxa, koji je svojim djelom Das Kapital „redkim znanjem narodno-gospodarstvenega slovstva" pokazao mnogostrano povijesno, filozofsko i klasično obrazovanje, kao i temeljito poznavanje literature na engleskom. Dakle, ono što Zarnikovu studiju odvaja od većine do sada razmatranih njegova je spremnost da slijedi Schäfflea u obrani profesionalne stručnosti i moralnog karaktera nabrojenih socijalista, među njima i Marxa. ${ }^{51}$

Vrlo je živopisno Zarnik opisao suprotstavljenost socijalista neobuzdanoj liberalnoj politici od koje koristi imaju samo bogatiji, a ne i radnici kojima liberalni zakoni ne garantiraju dnevni kruh. Stoga je, po njemu, potreban jednakomjeran razvoj individualne slobode i društvene jednakosti. ${ }^{52}$ Liberalizam Zarnik opisuje na primjeru učenja francuskih fiziokrata i britanske klasične ekonomske teorije te napominje da njemu komunisti suprotstavljaju svoje učenje o državi koja bi trebala u svoje ruke preuzeti cjelokupno društvo i kontrolirati sve njegove elemente. Kao prve protivnike klasične političke ekonomije navodi Simon-Nicholasa Henrija Lingueta i „komuniste“ Babeufa, Cabeta i Owena, a komunističko učenje sažima u trima postavkama: (a) svi su ljudi jednaki i jednakopravni, (b) svi imaju jednako pravo na prirodna dobra i (c) svi ljudi imaju jednake potrebe. Tome se Zarnik suprotstavlja jer vodi u drugu krajnost, a to je nasilno ujednačavanje ljudi, znatno ograničenje osobnih sloboda te uništenje kompetitivnosti i produktivnosti. ${ }^{53} \mathrm{Na}$ kraju se razmatra socijalizam pod kojim se razumije Blancovo učenje, koje Zarnik također kritizira te zaključuje da vodi u komunizam ako ga se dosljedno slijedi. ${ }^{54}$

S obzirom na to da su slovenske pokrajine tijekom šezdesetih doživjele industrijski uzlet, ne začuđuje da je tih godina značajno rastao broj radnika. ${ }^{55}$ Udruženja zanatlija javljaju se već od pedesetih godina, radnička udruženja krajem šezdesetih u Ljubljani, Mariboru i Celju, a prvi štrajkovi od 1870 . godine. ${ }^{56} \mathrm{U}$ travnju 1871. radničko prosvjetno društvo u Ljubljani nakratko je posjetio Johann Most koji je bio vatreni, ali i svojeglavi pristaša Marxa i Lassallea, pa je od tada društvo slijedilo Lassalleova načela. ${ }^{57}$ No, kako je Most prenio najnovija učenja „znanstvenog socijalizma“ tamošnjim radnicima nije poznato. Time se društvo ipak približilo politički i teorijski razvijenoj austrijskoj i njemačkoj socijaldemokraciji.

\footnotetext{
51 Isti, „Bivša parižka komuna in socijalizem III.“, Novice (Ljubljana), br. 28, 12. 7. 1871., 223-224.

52 Isti, „Bivša parižka komuna in socijalizem IV.“, Novice (Ljubljana), br. 30, 26. 7. 1871., 239-240; br. 31, 2. 8. 1871., 249-250.

53 Isti, „Bivša parižka komuna in socijalizem VI-VII.“, Novice (Ljubljana), br. 32, 9. 8. 1871., 254-255; br. 34 , 23.8. 1871., 273-274; br. 35, 30. 8. 1871., 283-284; br. 36, 6. 9. 1871., 288; br. 39, 27. 9. 1871., 312-313.

54 Isti, „Bivša parižka komuna in socijalizem VIII.“, Novice (Ljubljana), br. 46, 15. 11. 1871., 373; br. 47, 22. 11. 1871., $380-381$.

55 F. Gestrin i V. Melik, Istorija Slovenaca, 157-173; P. Vodopivec, Od Pohlinove slovnice do samostojne države, 98102.

56 F. Gestrin, „Uticaj Pariške komune na politički razvoj u Sloveniji“, 1039-1040.

57 „Arbeiterverein“, Laibacher Tagblatt (Ljubljana), br. 94, 25. 4. 1871.; V. MeLIK, „Pariška komuna i Slovenci“, 1031; F. Gestrin, „Uticaj Pariške komune na politički razvoj u Sloveniji“, 1042.
} 


\section{Prvotna recepcija Marxovih ideja u tisku i RADOVIMA NA SRPSKOME JEZIKU}

Glavni kulturni centri srpskoga naroda tijekom treće četvrtine 19. stoljeća nisu bili smješteni samo u Kneževini Srbiji, već i u ugarskome dijelu Habsburške Monarhije. Četrdesete godine 19. stoljeća svjedočile su rastu utjecaja tiska na srpskome jeziku i vatrenim raspravama o narodnome jeziku, a za Kneževinu su značile ustavobraniteljski period koji je pokušao raskinuti s osmanskim nasljeđem i okrenuti se europskim modelima u državnoj upravi. U takvu kontekstu europska revolucionarna zbivanja proširila su se na područja Habsburške Monarhije, a svoj su najjači odjek među Srbima imala u Vojvodini u obliku oružanih sukoba s Mađarima. ${ }^{58}$

Beogradske su novine budno pratile zbivanja u Europi nakon što je revolucija izbila u Parizu u veljači 1848. godine. ${ }^{59}$ Ipak, tijekom trajanja revolucije komunizam se vrlo rijetko spominjao, manje nego u slovenskom tisku i mnogo manje nego u Banskoj Hrvatskoj. Zanimljivo je da se jedan od rijetkih članaka koji spominje takve ideje zapravo bavio južnoslavenskim jedinstvom, a pojavio se u listopadu 1848., dakle u vrijeme dok je Jelačić stezao obruč oko Beča. Autor veliča Slavene, njihovu snagu i odanost hrabrome vodstvu nasuprot „komunističko-demokratičkoj, protuslavenskoj“ buni u Beču, jasno istaknuvši da nije „probitačno za nas Slavene, da komunizam pobedi“. Suprotstavljajući se suparnicima koji su ih pogrdno nazivali reakcionarima i apsolutistima, „Jugoslaveni“ sada moraju pobijediti za opću slavensku stvar i prevladati pokušaje da se sruši Austrija jer bi time pobijedila mađarska i pangermanska hegemonija, tvrdi autor. ${ }^{60}$ Jasno je, dakle, da je ovdje „komunizam“ bio tek pogrdna riječ za protivničku stranu, kao što je to bio čest slučaj u tadašnjoj Europi.

Ni u neposrednom postrevolucionarnom razdoblju na početku pedesetih Srpske novine ne zanimaju se za komunističke ideje u kojima su hrvatske i slovenske novine vidjele glavnog pokretača revolucije. Jedan je od rijetkih suprotnih primjera članak iz ožujka 1850., koji je sa zabrinutošću pratio propadanje srpskih seljaka u Vojvodini. Autor tvrdi da je težnja svih europskih vlada „da na put stanu socializmu i komunizmu“ koji potkopavaju „celo evropsko društveno stanje“ i stoga bi cilj austrijske Vlade trebalo biti sprečavanje procesa proletarizacije srpskih seljaka koji potkopava samu Austriju. ${ }^{61}$

Unatoč slaboj početnoj recepciji novih radikalnih ideja, sveukupni razvoj Kneževine od četrdesetih godina pogodovao je vrlo ranoj pojavi srpskih socijalista. Godine 1858. Svetoandrejska skupština označila je prvi val liberalizacije, šezdesetih godina osniva se Velika škola u Beogradu na kojoj se predaje o Saint-Simonu, Proudhonu, Herzenu, Černiševskom

\footnotetext{
58 Više o tome u Slavko Gavrilović, „Srbi u Habsburškoj Monarhiji od kraja XVIII do sredine XIX veka“, Istorija srpskog naroda, knj. V, tom II: Od Prvog ustanka do Berlinskog kongresa 1804-1878 (ur. Vladimir Stojanović), Beograd 1981., 45-108; Sima M. Ćirković, The Serbs, Oxford 2004., 196-203; Holm Sundhaussen, Geschichte Serbiens 19.-21. Jahrhundert, Köln 2007., 77-80.

59 „Francuzska“, Novine čitališta beogradskog (Beograd), br. 10, 2. 3. 1848., 86; „Francuska“, Srpske novine (Beograd), br. 18, 2. 3. 1848., 70 .

60 Đ. BošKović, „Jedna reč Jugoslavenima“, Srpske novine (Beograd), br. 90, 8. 10. 1848., 600.

61 „Telegrafske vesti. U Beču, u početku Marta“, Srpske novine (Beograd), br. 35, 23. 3. 1850., 126. O sličnim reakcijama neposredno nakon revolucije v. L. Perović, Srpski socijalisti 19. veka, knj. I, 159-160.
} 
i drugim ranim socijalistima, a srpska Vlada financira školovanje mladih ljudi u inozemstvu koji se vraćaju s novim i često radikalnim idejama te propituju poredak u Kneževini Srbiji. Iako je još sedamdesetih Srbija bila industrijski nerazvijena s tek 1500 radnika, upravo će se okretanje europskim modelima te u tradicionalnom seljačkom društvu omražena birokratizacija pokazati plodonosnima za socijalističke ideje. ${ }^{62}$

U srpskoj historiografiji navodi se da su tijekom šezdesetih i sedamdesetih godina 19 . stoljeća tadašnji studenti Svetozar Marković, Dragiša Stanojević i Pera Todorović bili među prvim srpskim misliocima koji su došli u plodonosan doticaj s Marxovom mišlju. ${ }^{63}$ Godinu prije uspostave Pariške komune Marković je u Pančevcu objavio članak „Društvena i politička borba u Evropi“ “. ${ }^{64}$ Suprotstavljajući se srpskim liberalima, njegov je glavni cilj bio pokazati sunarodnjacima uzroke sve učestalijih europskih revolucija te ih upozoriti da ne čine iste greške kao zapadnoeuropski narodi, kako bi izbjegli njihov bolni put. ${ }^{65}$ Kao pravo dijete historizma 19. stoljeća, Marković izlaže dugu povijest ekonomskog razvitka Zapadne Europe te utvrđuje da je trgovina prva uvela kapitalistički način proizvodnje koji treba slobodu od feudalnog poretka, a takva zahtijevanja ekonomskog liberalizma došla su do izražaja u Francuskoj revoluciji 1789. godine ${ }^{66}$ Veliki dio članka zauzima interpretacija revolucije u Francuskoj tijekom 1848. godine, koja nije uspjela jer je socijalistički tabor bio podijeljen (na socijaliste Saint-Simona i Fouriera, Cabetove komuniste, Blancove polukomuniste i Proudhonove mutualiste), zato što je bilo malo radnika, a puno neobrazovanih seljaka te konačno zbog urote liberala i monarhista protiv Blanca. ${ }^{67}$ Marković dijeli suvremene političke struje na konzervativno-nacionalnu koja putem Crkve najniže slojeve uči „trpljenju, praštanju i - ropstvu“ te želi „monopol u imanju, apsolutizam u državi i apsolutizam u crkvi“ radi starih povlastica, zatim „liberalno-demokratsku“ koja je nerazdruživo povezana s kapitalizmom, zbog čega želi potpunu ekonomsku i političku slobodu kako bi prisvojila sredstva za proizvodnju te stvorila klasu bijednih nadničara za izrabljivanje, i konačno „socijalno-demokratsku“ kojoj je posvećen zadnji dio članka. ${ }^{68}$

Upozoravajući da se među Srbima malo zna za novije „naučne“ radnje koje su izašle nakon 1848., a koje su socijalizmu dale znanstveni temelj, Marković na prvome mjestu navodi Marxov Das Kapital, zatim radove Marloa, Friedricha Alberta Langea, Lassallea te konačno Černiševskog koji spada među „najgenijalnije“ autore. Ipak, u razjašnjavanju načela „socijalno-demokratske stranke“ Marković se oslanja na kongrese Prve internacionale i na Marxa, kojega čitateljima predstavlja kao njemačkog komunista koji je napisao Internacionalin program, a kao njen datum osnivanja pogrešno navodi 1866. godinu. ${ }^{69}$ Marković

62 S. Ćirković, The Serbs, 207, 209; H. Sundhaussen, Geschichte Serbiens 19.-21. Jahrhundert, 78; L. Perović, Srpski socijalisti 19. veka, knj. I, 148-166.

63 L. Perović, Srpski socijalisti 19. veka, knj. I, 69-70.

64 Iako je Pančevac izlazio izvan Kneževine Srbije, u Vojnoj krajini u Habsburškoj Monarhiji, čitatelje je, dakako, nalazio velikim dijelom u Srbiji, na čiju su elitu Markovićevi članci bili upravljeni. V. Andrija RADENIĆ, „Srbi u Habsburškoj Monarhiji 1868-1878.“, Istorija srpskog naroda, knj. V, tom II: Od Prvog ustanka do Berlinskog kongresa 1804-1878 (ur. Vladimir Stojanović), Beograd 1981., 208.

65 Svetozar Marković, „Društvena i politička borba u Evropi“, Celokupna dela, knj. II, Beograd 1987., 275.

66 Isto, 97-99.

67 Isto, 110-113.

68 Isto, 104, 115-116.

69 Isto, 109, 117. 
smatra da je liberalizam u savezu s kapitalizmom preuzeo državne mehanizme kako bi nametnuo svoj sustav vrijednosti. Socijalizam je posve suprotstavljen interesu konzervativaca i liberalnih kapitalista jer želi raspustiti svu poslugu u službi magnata te činovništvo i stajaću vojsku koji su direktan teret narodu; kapital ne promatra kao element proizvodnje, već kao „nagomilani tuđ rad“ te uvodi takvu „organizaciju rada“ koja smatra da treba zadržati i tvornice i da radnik mora biti vlasnik proizvodnih sredstava, a to se može postići samo ako ta sredstva „u najopširnijem smislu te riječi (...) postanu kolektivna“. Jedino narod može odrediti društvene, političke i ekonomske odnose u državi, a za sve nabrojeno potrebno je obrazovanje radnika. ${ }^{70}$ Članak završava trijumfalnom tvrdnjom da na užas konzervativaca Internacionala raste i prodire čak i među seljaštvo te prijetećim Marxovim riječima koje Marković donosi u prijevodu: „Sila je babica koja oslobađa stara društva od porođaja, kad su se u njima začela nova društva“, a cilja na „partiju koja gospoduje“, ali koja još ima vremena da se „opameti“.71

$\mathrm{Na}$ Markovićev je članak odgovorio Dragiša Stanojević, ${ }^{72}$ suprotstavljajući se njegovu prikazu liberalizma koji zapravo štiti narod od tirana i slaboga (radnika) od jačega (kapitalista). Sloboda za koju se liberalizam zalaže nije neograničena, nego je sloboda da se nešto učini, pa tako i štiti slabijega. Također mu je prigovorio da u svome razmatranju kapitala neopravdano uopćava kapital „parazita“ na kapital općenito. Socijalizam je utopistička ideja koja želi ostvariti najskuplju slobodu potpuno nezavisne materijalne egzistencije svakog čovjeka, uzvraća Stanojević, i „Markovićev“ je Marx u krivu kada je „nakazu od slobode“ predstavio kao pravu slobodu liberala. Štoviše, Marković bi „iz učtivosti (...) prema diktatorskom komunistu Marxu“ upotrijebio državu za rješavanje radničkog pitanja, zanijekao bi političku slobodu, odnosno parlamentarizam, jednakost i osobnu slobodu građana, slobodu tiska i udruživanja te bi se priklonio diktatorskom „komunističkom komitetu“. Protiv toga Stanojević smatra kako je nužno da radništvo u demokratskom sustavu progura svoju volju, a to može na lokalnoj (općinskoj) razini, dok bi državna vlast garantirala političku slobodu svim građanima. ${ }^{73} \mathrm{Na}$ Stanojevićeve je prigovore Marković odgovorio da su upravo liberali u povijesti zastupali laissez faire u ekonomskoj politici te se potužio na izvrtanje njegovih riječi, detaljnije razloživši svoje stajalište u vezi s pojmom liberalizma kao „cjelokupnog društvenog sistema“ koji socijalna demokracija treba srušiti i kapitala pod kojim shvaća od radnika otuđena sredstva za proizvodnju. Zanimljiva je i Markovićeva obrana načela Prve internacionale i Marxa koji je, po njemu, prvi uvidio da klasična liberalna ekonomija nije otkrivala ekonomske zakone uopće, već samo one koji su vrijedili za kapitalističko društvo, da je nemoguće pomiriti radnika i kapitalista, stoga se socijalno pitanje neće moći riješiti mirnim putem, kao i da će politička vlast nestati kada nestane klasnih razlika. Unatoč tomu, u članku Marković tvrdi da Marx ne zagovara „diktatorski komunizam“ jer želi

\footnotetext{
70 Isto, 108-109, 119.

71 Isto, 99, 121. Marxove riječi na njemačkom glase: „Die Gewalt ist der Geburtshelfer jeder alten Gesellschaft, die mit einer neuen schwanger geht.“ „Rečenica se doslovno može prevesti kao: ,Sila je babica svakoga staroga društva, koje zatrudni s novim [društvom, op. a.]', odnosno, u prenesenom značenju, društva koje snuje novo društvo." V. K. Marx, Das Kapital. Kritik der politischen Ökonomie, K. Marx i F. Engels, Werke, Bd. XXIII, Berlin 1962., 779.

72 O njemu v. L. Perović, Srpski socijalisti 19. veka, knj. I, 223-306.

73 Dragiša Stanojević, „Društvena i politička borba u Evropi'“, S. Marković, Celokupna dela, knj. II, $241-249$.
} 
uvjeriti „masu naroda koja trpi od manjine“ da sruši sadašnju vlast. ${ }^{74}$ Tu je Stanojević lako mogao pokazati Markovićevu proturječnost u vezi s ljudskim pravima jer je naglašavao da želi srušiti liberalizam kao cjelokupni društveni sistem te ugušiti individualne sposobnosti i konkurenciju, a ujedno je tvrdio da ipak želi zadržati postojeće političke slobode. ${ }^{75}$

S obzirom na to da su, dakle, u Srbiji postojali intelektualci socijalističkog usmjerenja koji su žestoko napadali postojeći društveni poredak i prije uspostave Pariške komune, jasno je da će recepcija događaja u Parizu te uloge Internacionale i Marxa biti ponešto drugačija nego u Banskoj Hrvatskoj, Dalmaciji ili u slovenskim pokrajinama, unatoč tomu što su ti krajevi bili industrijski razvijeniji. Kada je izbio Francusko-pruski rat, Marković je krivio obje strane, ali je za vladavinu Napoleona III. ustvrdio da je manje narodna od Bismarckove. Smatrao je tragedijom da „rođeni sinovi“ naroda moraju poginuti od neprijateljske puške kako bi se ostvarile pozitivne vrijednosti „načela narodnosti“, a to je nezavisnost svakog naroda, na čemu se temelje sloboda, bratstvo i jednakost. ${ }^{76} \mathrm{Kada}$ je, pak, izbila Pariška komuna, njoj su se suprotstavili krugovi bliski Srpskoj pravoslavnoj crkvi i vlastima u Kneževini Srbiji, a najveću je simpatiju uživala među omladinom, đacima i studentima Velike škole u Beogradu, sitnim građanstvom i liberalima te na stranicama Pančevca, Zastave i Markovićeva novopokrenutoga Radenika. ${ }^{77}$

S obzirom na polemiku sa Stanojevićem od godinu prije, ironično je da je Marković branio Parišku komunu kao suverenu općinu koja može autonomno donositi odluke. A kada je ona pala, žestoko ju je branio od nasrtaja novina koje su zapravo htjele osporiti njena „napredna politička načela“ ${ }^{78}$ Kao najobičniju „sokak-lakrdiju“, ismijavao je Favreovu okružnicu i vijesti u novinama koje su iza Pariške komune vidjele urotu Marxa, Internacionale (čiji je rad javan) i izmišljenih likova poput Diebnika te ljudi koji s Internacionalom nemaju veze. ${ }^{79}$ Valja napomenuti da je u jeku borbi oko Pariške komune (travanj/svibanj 1871.) u Pančevcu u nastavcima objavljen srpski prijevod Marxova i Engelsova Das Manifest der Kommunistischen Partei, koji se pretiskavao u posebne knjižice i zatim odašiljao u Srbiju. Marković je u isto vrijeme u Radeniku objavio prijevode Marxova spisa The Civil War in France i poglavlja iz njegova djela Das Kapital. ${ }^{80}$

74 S. Marković, „Kritika na 'Društvenu i političku borbu u Evropi““, Isti, Celokupna dela, knj. II, $136-149$.

75 D. Stanojević, „G. Svetozaru Markoviću“, S. Marković, Celokupna dela, knj. II, 259-270. Što se tiče pitanja Marxove teorije slobode (volje), može se spomenuti (bez detaljnijeg ulaženja u filozofsku problematiku) da je on zastupao kompatibilizam, odnosno da je sloboda spoznata nužnost koja je uvjetovana društvenim sustavom. V. Allen W. Wood, Karl Marx, 2. izd., New York 2004., 118.

76 S. Marković, „Francuska i Pruska“, Isti, Celokupna dela, knj. II, 132-135.

77 Dragoslav Janković, „O društveno-političkim prilikama u Srbiji u doba Pariške komune“, Pariška komuna 18711971 (ur. Pero Damjanović i Ašer Deleon), Beograd 1971., 797-802; Nikola Petrović, „Odjeci Pariške komune u srpskoj javnosti Vojvodine i Ujedinjenoj omladini srpskoj“, isto, 803-822. O Radeniku v. Dragić Kačarević, „Programi 'Radenika', 'Vragolana', 'Jednakosti' i 'Javnosti', najranijih srpskih socijalističkih listova“, Počeci socijalističke štampe na Balkanu (ur. Milo Popović i dr.), Beograd 1974., 113-136; Katarina Trifunović, „Ekonomske koncepcije 'Radenika'“, isto, 155-169; Mihailo BjeliCa, „Finansiranje 'Radenika'“, isto, 171-175; L. Perović, Srpski socijalisti 19. veka, knj. II, 304-307.

78 S. Marković, „Pariška komuna. Pitanje o hlebu i samoupravi“, Isti, Celokupna dela, knj. IV, Beograd 1995., 83-87; Isti, „Pogibija Pariške komune“, isto, 93-98.

79 Isti, „Pariška komuna i Internacijonala“, Isti, Celokupna dela, knj. IV, 117-124.

80 L. Perović, Srpski socijalisti 19. veka, knj. II, 70-71; A. Radenić, „Srbi u Habsburškoj Monarhiji 1868-1878.“, 208. 
Dakako, bilo je članaka na srpskome jeziku koji su imali posve drugačije shvaćanje ideja koje je promovirala Pariška komuna i koji su pokazivali da ne mare puno za Markovićeva upozorenja o najnovijem razvoju socijalističkih učenja. Po zanimljivim zapažanjima ovdje posebno treba istaknuti anonimni članak „Socijalizam i komunizam“ koji se pripisuje političaru Svetozaru Miletiću, a objavljen je u Zastavi u travnju 1871. On ustaje u obranu osobne slobode i vlasništva pred komunizmom i socijalizmom koji počinje onda kada radnici, plemenito zahtijevajući slobodu, bratstvo i jednakost u načelu, u sâm život uvode nejednakost. Pod komunistima navode se Louis-Auguste Blanqui i članovi Prve internacionale, kojima je cilj (za razliku od socijalista) potpuno dokrajčiti postojeći pravni i ekonomski poredak, državu, pravo vlasništva i obiteljske odnose. Miletić primjećuje da su i demokrati i socijalisti i komunisti svoje ciljeve htjeli ostvariti centralizacijom, a sada se najednom okreću slobodnoj općini, što vodi fragmentiranju vlasti i u konačnici u Proudhonovu anarhiju. Poput Stanojevića, Miletić ističe da je liberalizam koji komunisti napadaju „nadriliberalizam“ te da „(...) solidarnosti ima mesta u slobodi, slobodi pak nema mesta u solidarnosti u iznuđenoj, primoranoj asocijaciji. U komunizmu čovek tek postaje pravi rob“. ${ }^{81}$

Jasno je, dakle, da početkom sedamdesetih većina srpskih intelektualaca nije mnogo marila za Marxove teorije te su njenim postavkama bili suprotstavljeni, a i za prvoga srpskoga socijalista Markovića već dugo postoje prijepori u historiografiji je li on bio marksist ili u nekim važnim pogledima suprotstavljen Marxu. ${ }^{82}$

\section{Komparativni UVID U PRVU RECEPCIJU MarXove misli MeĐu JuŽnim Slavenima u Habsburškoj Monarhiji i SRbiji}

Nakon svega izloženog, komparacija istraživačkih rezultata o prvotnoj recepciji Marxove misli među spomenutim južnoslavenskim narodima pruža vrlo zanimljive uvide u „pretpovijest" razvitka socijaldemokracije na ovim prostorima, odnosno jednoga procesa koji će simbolično završiti na Kongresu ujedinjenja ljevice u Beogradu u nestabilnome razdoblju neposredno nakon završetka Prvoga svjetskoga rata.

Za vrijeme revolucije 1848. i neposredno poslije nje Marx je među hrvatskim i slovenskim intelektualcima te u tisku njihovih zemalja bio tek jedna minorna figura potisnuta pod slavnijim imenima francuskih anarhista i ranih socijalista koje se svrstavalo u neodreden termin „komunizma“. Prema tim novim lijevim idejama pogotovo je hrvatski tisak, zbog njihove radikalnosti i svoje afilijacije u revolucionarnim zbivanjima, bio neprijateljski

81 Svetozar Miletić, „Socijalizam i komunizam. 'Komuna' i 'Februarska republika', Pariška komuna 1871-1971 (ur. Pero Damjanović i Ašer Deleon), Beograd 1971., 890-894. Inače će Zastava zbog svojih republikanskih shvaćanja sve pozitivnije pisati o Pariškoj komuni jer je u njenim protivnicima vidjela monarhiste. V. N. Petrović, „Odjeci Pariške komune u srpskoj javnosti Vojvodine i Ujedinjenoj omladini srpskoj“, 803-816.

82 Usp. Pero Damjanović, „Svetozar Marković u odnosu na zapadnoeuropski socijalizam u doba Pariške komune“, Pariška komuna 1871-1971 (ur. Pero Damjanović i Ašer Deleon), Beograd 1971., 823-855; L. Perović, Srpski socijalisti 19. veka, knj. II. 
nastrojen, dok ih je tisak u Srbiji također spominjao u negativnome svjetlu, ali i vrlo rijetko, s obzirom na to da je bio udaljeniji od zbivanja u revolucijom prožetoj Habsburškoj Monarhiji.

Nakon određenog je perioda tišine, prije zbivanja oko Pariške komune, krajem šezdesetih i na samome početku sedamdesetih, Marx izgradio svoju reputaciju zahvaljujući ulozi u Prvoj internacionali te kao ugledan intelektualac koji je tvrdio da je socijalizmu dao znanstveni temelj u prvome svesku djela Das Kapital. O tome je, slijedom jačanja utjecaja njemačke i austrijske socijaldemokracije, izvještavao hrvatski i slovenski tisak, a još i detaljnije onaj srpski zahvaljujući ranoj pojavi prvog srpskog socijalista, Svetozara Markovića. Uspostavom Pariške komune većina će hrvatskih, srpskih i slovenskih novina, pod utjecajem političkog razvoja događaja i stranoga tiska, osuđivati Marxa i Internacionalu. Iako je u tome bilo iznimaka, pa se pod utjecajem njemačke i austrijske socijaldemokracije tih godina odvijaju zamjetnija događanja u hrvatskom i slovenskom radničkom pokretu, intelektualci umjerenih političkih stajališta više nisu jednoglasno ismijavali nova socijalistička učenja, a pojavljuju se i hrvatski, srpski i slovenski socijalisti koji počinju aktivno djelovati, ipak je sve to još uvijek bilo daleko izvan prevladavajućih političkih strujanja.

$\mathrm{Na}$ kraju valja još naglasiti i različitost državno-pravnog okvira unutar kojega je hrvatski, srpski i slovenski tisak izlazio i na čijim su stranicama gore spomenuti intelektualci objavljivali svoje radove. Iako je u ovome razdoblju i u Habsburškoj Monarhiji i u Kneževini Srbiji iz razumljivih razloga pritisak na radikalnu ljevicu bio snažan, ipak je povijesna činjenica da je ona lakše razvijala svoju djelatnost u Srbiji. Razlozi za to ipak su previše kompleksni da bi ih se razmatralo u okviru ovoga rada.

\section{ZAKLJUČAK}

Stare Koraćeve tvrdnje o tome da u najranijim počecima radničkog pokreta među $\mathrm{Hr}$ vatima nema nikakvih „modernih socijalističkih stremljenja i teoretisanja“ svakako su već odavno revidirane, ali one više ne bi smjele odvraćati ni istraživače intelektualne povijesti. Takvo gledište donekle vrijedi samo ako se istraživač ograniči isključivo na intelektualce socijalističke orijentacije. Međutim, u povijesti razvitka određenih ideja jednako je važno proučavati i one intelektualce koji su se njih doticali, iako su prema njima držali odmak ili su bili posve neprijateljski raspoloženi. To jednako vrijedi i za najraniju recepciju Marxovih ideja koje će biti važne za razvoj hrvatske, srpske i slovenske socijaldemokracije. Ozbiljni članci i studije anonimnih autora koje se mogu naći na stranicama hrvatskog tiska, kao i slovenskih intelektualaca poput Kluna i Zarnika, nisu puno manje vrijedne proučavanja od ranih Markovićevih radova, iako su potonjemu zbog socijalističkih uvjerenja tada najnoviji Marxovi radovi bili područje posebnog interesa i detaljnijeg proučavanja. U svakom slučaju, proučavanje radova svih tih intelektualaca pruža cjelovitiju sliku intelektualne atmosfere u kojoj su Marxove ideje bile (ne)prihvaćene među Južnim Slavenima u Habsburškoj Monarhiji i Srbiji i neka zajednička obilježja u toj recepciji, poput važnosti turbulentnih europskih zbivanja od 1848. do 1871. godine za početno prodiranje radikalnijih lijevih ideja. 


\section{$\cos$}

\section{The EARliest ReCEPTION OF MARXist THOUght AMONG The Southern Slavs in the Habsburg Monarchy and SERBIA (I848 - I87I)}

The paper analyzes the reception of Marx thought among the Southern Slavs in the Habsburg Monarchy and Serbia and subsequently the often neglected "prehistory" of Croatian, Serbian and Slovenian social democracy, while using the methodology of non-Marxist historiography. It starts by providing an overview of past historical research on the topic and goes on to conclude that Croatian, Slovenian and Serbian historiography, even when they shared a country, never attempted to approach the subject in a methodologically unified way, nor did they use the methods of comparative history to reach new conclusions in researching the earliest reception of modern socialist teachings and the beginnings of the worker's movement. The main section of the paper is divided into three parts: the reception of Marx's ideas (a) in Banska Croatia and Dalmatia, (b) in Slovenian provinces and (c) in the press and papers published in the Serbian language. The paper covers the period between the revolutions of 1848 and the Paris Commune of 1871, because the intellectual discussions that these events gave rise to, in which Marx was heavily involved, were reported on extensively by the Croatian, Serbian and Slovenian press. The paper focuses on examining these press reports in light of the latest historical insights. Finally, it presents the results of a comparative analysis of the reception of Marxist thought among the Croats, Serbs and Slovenians. What transpires is that there are many similarities in the ways in which Marxist thought was received in Croatia, Serbia and Slovenia. During the revolutions of 1848 Marx's ideas were suppressed under the negative label of communism, which was conflated with mostly French anarchists and early socialists, as well as various political forces that were antagonistic towards Southern Slavs. In the second half of the 1860s and the early 1870s, with the strengthening of the German and Austrian social democracy, the press started reporting on Marx because of his role in the First International and his book Das Kapital, whereas after the creation of the Paris Commune, these reports in Croatian, Serbian and Slovene-language press again turned unfavourable, with few exceptions, like the Slovene lawyer Valentin Zarnik and the Serbian socialist Svetozar Marković.

Key words: Karl Marx, communism, socialism, the Habsburg Monarchy, Banska Croatia, Dalmatia, Slovenian provinces, the Principality of Serbia, intellectual history

\section{$\cos$}

\section{Izvori}

Agramer (politische) Zeitung (Zagreb)

Cillier Zeitung (Celje)

Laibacher Tagblatt (Ljubljana)

Novice (Ljubljana)

Novine čitališta beogradskog (Beograd)

Novine horvatsko-slavonsko-dalmatinske / Novine dalmatinsko-hervatsko-slavonske / Narodne novine (Zagreb) 
Slovenski narod (Maribor)

Srpske novine (Beograd)

(Vereinigte) Laibacher Zeitung (Ljubljana)

Zatočnik (Sisak)

\section{Primarna literatura}

Lazar Hellenbach, Misli o socialnoj politiki u Austriji, Zagreb 1862.

Svetozar Marković, Celokupna dela, knj. II, IV, Beograd 1987., 1995.

Karl Marx i Friedrich Engels, Gesamtausgabe, erste Abteilung, Bd. XXII: Werke, Artikel, Entwürfe, März bis November 1871, Berlin 1978.

Karl Marx i Friedrich Engels, Werke, Bd. IV, VI, XXIII, Berlin 1959., 1961., 1962.

Svetozar Miletić, „Socijalizam i komunizam. 'Komuna’ i ‘Februarska republika', Pariška komuna 1871-1971 (ur. Pero Damjanović i Ašer Deleon), Beograd 1971., 890-894.

Albert Eberhard i Friedrich Schäfrle, Kapitalismus und Socialismus, Tübingen 1870.

\section{Sekundarna literatura}

Mihailo BJELICA, „Finansiranje 'Radenika'“, Počeci socijalističke štampe na Balkanu (ur. Milo Popović i dr.), Beograd 1974., 171-175.

Stjepan Blaženović, Pomoćni priručnik za historiju medunarodnog radničkog pokreta i historiju KPJ, Zagreb 1958.

Josip CaZI, Prva radnička društva u Hrvatskoj (1860-1880), Zagreb 1957.

Josip CAZI, Radnički pokret Hrvatske 1860-1895, Beograd 1962.

Sima M. Ćirković, The Serbs, Oxford 2004.

Vasa Ćubrilović, Istorija političke misli u Srbiji XIX. veka, Beograd 1982.

Pero Damjanović, „Svetozar Marković u odnosu na zapadnoeuropski socijalizam u doba Pariške komune“, Pariška komuna 1871-1971 (ur. Pero Damjanović i Ašer Deleon), Beograd 1971., 823-855.

Morna Daniels, „French Newspapers and Ephemera from the 1848 Revolution“, British Library Journal, 24/1998., 219-233.

Miroslava Despot, „Nekoliko podataka o prilikama u zagrebačkoj tvornici koža 70-ih godina 19. stoljeća“, Historijski zbornik, 29-30/1976. - 1977., 377-383.

Miroslava Despot, „Počeci radničkog pokreta i političke prilike u Hrvatskoj u doba Pariške komune", Pariška komuna 1871-1971 (ur. Pero Damjanović i Ašer Deleon), Beograd 1971., 965-983.

Sergije Dimitrijević, Socijalistički radnički pokret u Srbiji 1870-1918, Beograd 1982.

Slavko GaVriLović, „Srbi u Habsburškoj Monarhiji od kraja XVIII do sredine XIX veka“, Istorija srpskog naroda, knj. V, tom II: Od Prvog ustanka do Berlinskog kongresa 1804-1878 (ur. Vladimir Stojanović), Beograd 1981., 45-108.

Ferdo Gestrin, „Uticaj Pariške komune na politički razvoj u Sloveniji“, Pariška komuna 18711971 (ur. Pero Damjanović i Ašer Deleon), Beograd 1971., 1037-1050.

Ferdo Gestrin i Vasilij Melik, Istorija Slovenaca od kraja osamnaestoga stoljeća do 1918, Sarajevo 1979.

Mirjana Gross, Izvorno pravaštvo. Ideologija, agitacija, pokret, Zagreb 2000.

Mirjana Gross, „Počeci radničkog pokreta u Zagrebu“, Historijski zbornik, 8/1955., 1-39. 
Dragoslav Janković, „O društveno-političkim prilikama u Srbiji u doba Pariške komune“, Pariška komuna 1871-1971 (ur. Pero Damjanović i Ašer Deleon), Beograd 1971., 797-802.

Dragić Kačarević, „Programi ‘Radenika', 'Vragolana', 'Jednakosti’ i 'Javnosti', najranijih srpskih socijalističkih listova", Počeci socijalističke štampe na Balkanu (ur. Milo Popović i dr.), Beograd 1974., 113-136.

Vitomir Korać, Povijest radničkog pokreta u Hrvatskoj i Slavoniji, knj. I-III, Zagreb 1929. - 1933.

Anton KRISTAN, O delavskem in socijalističnem gibanju na Slovenskem do ustanovitve jugoslovanske socijalnodemokratične stranke (1848-1896), Ljubljana 1927.

Dragiša LAPČEvić, Istorija socijalizma u Srbiji, Beograd 1922.

Franz Mehring, Gesammelte Schriften, Bd. III: Karl Marx: Geschichte seines Lebens, Berlin 1960.

Vasilij Melik, „Pariška komuna i Slovenci“, Pariška komuna 1871-1971 (ur. Pero Damjanović i Ašer Deleon), Beograd 1971., 1017-1036.

Stijepo Овар, „Odjek Pariške komune u stranačkom životu Dalmacije“, Pariška komuna 18711971 (ur. Pero Damjanović i Ašer Deleon), Beograd 1971., 984-988.

Vlado OšTrić, „Prilozi pitanjima početaka radničke i socijalističke štampe u sjevernoj Hrvatskoj (1869-1890)“, Počeci socijalističke štampe na Balkanu (ur. Milo Popović i dr.), Beograd 1974., 45-84.

Latinka Perović, Srpski socijalisti 19. veka, knj. I-II, Beograd 1985.

Marija Mojca Peternel, „Soziale, nationale und politische Emanzipation der Slowenen in der Zeitung im Jahre 1848“, Povijesni prilozi, 41/2011., 233-253.

Nikola Petrović, „Odjeci Pariške komune u srpskoj javnosti Vojvodine i Ujedinjenoj omladini srpskoj“, Pariška komuna 1871-1971 (ur. Pero Damjanović i Ašer Deleon), Beograd 1971., 803-822.

Andrija Radenić, „Srbi u Habsburškoj Monarhiji 1868-1878.“, Istorija srpskog naroda, knj. V, tom II: Od Prvog ustanka do Berlinskog kongresa 1804-1878 (ur. Vladimir Stojanović), Beograd 1981., 153-275.

Jovan Skerlić, Svetozar Marković. Njegov život, rad i ideje, Beograd 1910.

Jonathan Sperber, Karl Marx. A Nineteenth Century Life, New York 2013.

Marcelo R. Sтамм, „Konstellationsforschung - Ein Methodenprofil: Motive und Perspektiven“, Konstellationsforschung (ur. Martin Mulsow i Marcelo Stamm), Frankfurt am Main 2005., 3173.

Nikša Stančić, „Godina 1848.“, Hrvatska i Europa. Kultura, znanost i umjetnost, sv. IV: Moderna hrvatska kultura od preporoda do moderne (XIX. stoljeće) (gl. ur. Mislav Ježić), Zagreb 2009., 63-75.

Holm Sundhaussen, Geschichte Serbiens 19.-21. Jahrhundert, Köln 2007.

Katarina Trifunović, „Ekonomske koncepcije 'Radenika', Počeci socijalističke štampe na Balkanu (ur. Milo Popović i dr.), Beograd 1974., 155-169.

Peter Vodopivec, O gospodarkih in socialnih nazorih na Slovenskem v 19. stoletju, Ljubljana 2006.

Peter Vodopivec, Od Pohlinove slovnice do samostojne države, Ljubljana 2007.

Allen W. Wood, Karl Marx, 2. izd., New York 2004. 